ISSN(print): 2643-9840, ISSN(online): 2643-9875

Volume 04 Issue 06 June 2021

DOI: 10.47191/ijmra/v4-i6-19, Impact Factor: 6.072

Page No.- $808-816$

\title{
The Effect of Foreign Debt and Taxation on Government Expenditure in Kenya
}

\author{
Dr. Angela Mucece Kithinji \\ School of Business University of Nairobi 0010030197 Kenya
}

ABSTRACT: Cases of high levels of public debt have mostly been reported in many developing countries part of which is debt borrowed abroad. Foreign debt is more preferable by many developing countries because it is cheaper to service in terms of interest costs. These countries tax their citizens heavily to raise enough finances to pay foreign debt. It was thus feasible to establish the influence of the foreign debt and taxation on expenditure of the Kenyan government. The study employed a causal research design. The period under study ranged from 2002 to 2017 . The study used secondary data which was extracted from the National Bureau of Statistics, and National Economic Surveys which were available at the Government of Kenya website. Correlation statistics were conducted to establish the association between variables. Regression analysis was used to establish the effect of foreign debt and taxation on government expenditure in Kenya. The findings revealed that foreign debt and taxation influences government expenditure individually. However, on the test of the joint effect, only taxation was found to influence public expenditure significantly unlike foreign debts.

KEYWORDS: Government Expenditure, Foreign Debts, Taxation

\section{INTRODUCTION}

Many developing countries prefer raising foreign debt because it is cheaper. Increasing taxation then becomes necessary to enable these countries to raise sufficient finances to enable these countries to service their foreign debt. The debt servicing ratio of foreign debt is lower than that of domestic debt. Kenya as a developing country not only services the foreign debt but the domestic debt as well. Many countries therefore depend mainly on taxation as a means of generating the required resources to meet their expenditure requirements. These countries will likely find themselves in growing fiscal imbalances when their revenue productivity falls below their expenditures. The efficacy of fiscal adjustment to accomplish fiscal obligations depends on the tax base or capacity relative to the expenditure requirements of the public sector. To achieve high fiscal performance, the various facets of revenue and expenditure estimates must be meticulously systematized and minutely analyzed within the general macroeconomic framework. Proper analysis and adequate harmony is necessary to enable revenue and expenditure policies formulated to produce high fiscal performance (Kusi, 1998).

High debt servicing has thrown developing countries into a "debt trap" depriving them of the resources needed to secure longterm economic development and build up strong social and physical infrastructure. Essentially, good debt management will not by itself guarantee against future debt crises which are beyond government control, because governments have to borrow anyway, but it can however reduce a country's vulnerability to external and internal shocks. Debt market crises sometimes occur even where there are sound macroeconomic policy settings with risky debt management practices increasing the vulnerability of the economy to economic and financial shocks (GoK, 2011/2012). Policy makers on debt levels therefore need to not only monitor the levels of debt but also how the debt raised and how it is used including monitoring the implementation of the projects that are financed using borrowed money. The practice is that foreign lenders tend to direct how the money that they lend to developing countries should be utilized by imposing donor conditionalities on foreign lending.

Many developing countries are faced with high levels of expenditure while revenue levels are relatively low. Essentially, weak revenue generation systems have been accused to be contributing to big debt levels. Enactment of revenue eroding measures by the governments and overspending tend to have implications on the amount of public debt to be raised. These governments are therefore forced to raise debt to finance the activities which government cannot afford to finance with the revenue generated using economic resources (IMF \& World Bank, 2001). Public debt is often a country's largest liability especially in developing 


\section{The Effect of Foreign Debt and Taxation on Government Expenditure in Kenya}

countries where a considerable amount of national revenue is spent repaying such debt leaving very little for use in financing government economic activities. The fiscal policy of any government is designed to deliver sound public financing including a commitment to medium-term objectives combined with the flexibility to respond to changing economic conditions in the shortterm (Bank for International Settlement, Basel, 1999). Its measurement takes into consideration cyclical movements in the economy such as scaling public debt as a proportion of GDP to provide some insight into cyclical patterns in the economy. GDP is said to react more too monetary policy than fiscal policy and additionally policy moves by monetary authorities take effect faster than fiscal policy action. Some theorists however argue that the reverse is the case (Melecky, 2012). Interestingly it is also important to determine how foreign borrowing influences taxation as well as government expenditure for purposes of informing policy on borrowing abroad by governments.

Many developing countries are rarely able to raise sufficient revenues to enable them finance all their activities. This implies that most of these countries find themselves with huge budget deficits. Buchanan and Wagner (1977) posits that the rapid increase in government spending is caused by large deficits the argument being that the deficits are there anyway. The hypotheses for taxation and government spending are the tax-spend hypothesis and the spend-tax hypothesis. The tax-spend hypothesis contends that government revenues have a positive effect on government expenditures and conversely, reductions in government revenues reduces government expenditures. The spend-tax hypothesis on the other hand argues that the political system somehow determines how much to spend and then makes the adjustments in tax policy and revenue sources to finance the government spending (Abdul and Muzafar, 2002; Wahid, 2008).

Osoro (1997) observes that low tax collection causes high and persistent deficits and maintains that such high deficits would be eliminated or substantially reduced by designing policies that would raise more tax revenues or improve tax collection. The author observed that government efforts to raise taxes will fail to reduce deficits if they do not go hand in hand with measures to reduce public spending. As countries embark on tax reform programs, they should also put measures in place to tame inflation such that benefits accruing from tax reforms are not eroded by high inflationary pressures while ensuring that government expenditures are kept under control to avoid eroding the benefits derived accruing from increased tax revenue (Farhadian-Lorie and Katz, 1990). Ordinarily, a country will not benefit significantly from high tax revenues if expenditures of government are not properly managed. In a number of countries government's ability to raise revenues or secure financing has been severely restricted by poor economic performance. (Mutambi, 2001; Kusi and Mc Grath, 1998). Saede (1990) observe that in the presence of capital inflows, the overall level of activity in the economy is artificially and temporarily increased through the foreign borrowing, and so is the aggregate tax base. When Governments find themselves running huge budget deficits, they might be forced to embark on one or more of the following approaches. Government could opt for discretionary tax measures (DTMS). This option tends to raise tax burden and is usually politically unpopular. Borrowing from the Central Bank fuels inflationary tendencies, whereas borrowing from the public especially through high yielding treasury bills exerts an upward pressure on other interest rates hence impeding private sector borrowing (Siegel, 1979; Saede, 1990).

Many countries undertake tax reforms with the objective of improving the efficiency of tax administration and subsequently increase the amount of tax revenue (Ghura, 1998). Tax reforms are also implemented with the objective of achieving revenue adequacy, economic efficiency, equity and fairness, and simplicity. Administration reforms introduced to address tax administration issues include introduction of a revenue agency such as the Kenya Revenue Authority (KRA) or the Uganda Revenue Authority (URA) to collect taxes. The agency approach is normally expected to increase the responsiveness of Government to the taxpayer in terms of genuine tax structure demands and reforms and also speedier enforcement on tax defaulters (Chipeta, 1998; Kusi and Mc Grath, 1994).

An assessment of the effect of public debt issuance on the key Expenditures have persistently exceeded the revenues and both have maintained consistent growth patterns. Prior to the 1973/74 oil crisis, total revenue matched total expenditure. The country started to experience serious budget deficits thereafter calling for external sources of finance (Osei, 1998) macroeconomic variables is important to the policy makers for them to formulate the right policies which would ensure that the levels of public debt assume a downward trend. In the Philippines, the national government coordinates monetary policy and public debt management through a seat in the Monetary Board and the government participates in macroeconomic coordination through the Board of the National Economic and Development Authority (NEDA Board) (Redoblado; 2011). A country's public debt has implications on the national budget in addition to impacting on the macroeconomic variables since government borrowing is necessitated to bridge the government budget deficit. Thus Public sector borrowing should also be entrenched in the budgetary process to ensure that the debt raised is in tandem with the budgeted debt levels (Guinigundo, 2015). Essentially it is also important to ensure that budgeted debt levels (may it be domestic public debt or foreign public debt) is within the acceptable limits relative to the bigger fiscal budget. (Alesina, et. al. 1992).

The problem of unsustainable public debt has brought many countries into deep economic crisis leading to regional and global 


\section{The Effect of Foreign Debt and Taxation on Government Expenditure in Kenya}

crises. A government's debt portfolio often contains complex and risky financial structures which can generate substantial risk to the government's balance sheet and to the country's financial stability. Excessive levels of debt that result in higher inter est rates can have adverse effects on real output. Governments should seek to ensure that both the level and rate of growth in their public debt is sustainable, and can be serviced under a wide range of circumstances while meeting cost and risk objectives. At the policy level debt managers should ensure that the fiscal authorities are aware of the impact of government financing requirements and debt levels on borrowing costs. It then becomes necessary to correlate public borrowing levels and financing of government projects that contribute to not only economic growth but to economic development in the long-term. Poorly structured debt in terms of maturity and currency or interest rate composition and large and unfunded contingent liabilities have been important factors in propagating economic crises in many countries.

The challenges of managing public debt differ from country to country and in some cases access to concessional borrowing - low interest loans with long payback periods - and debt restructuring take priority while in other countries access to the capital market is more important but in all cases governments have the ability to manage public debt effectively. Many countries particularly in Africa borrow more from the financial market using tradable and non-tradable debt instruments and borrow very little from financial institutions directly. Essentially, there is need to decide whether these governments are going to raise debt from domestic sources or from external sources. One of the determinants of the source of debt is the maturity structure as well as the servicing cost of the debt. Many poor countries particularly in Africa resort to external borrowing to finance their public development program's as domestic savings alone are not sufficient (Harding \& Pagan, 2002). However, these countries are not able to raise sufficient foreign debt due to conditionality's imposed by the lender countries. They thus result to borrowing domestically despite the high cost of domestic debt and its high servicing costs.

Sovereign debt management is the process of establishing and executing a strategy for managing the government debt in order to raise the required amount of funding, achieve its risk and cost objectives and to meet any other sovereign debt management goals the government may have set, such as developing and maintaining an efficient market for government securities. If macroeconomic policy settings are poor, sound sovereign debt management may not by itself prevent any crisis (Davide, 2016). Sound debt management policies reduce susceptibility to contagion and financial risk by playing a catalytic role for broader financial market development and financial deepening. Measures such as lengthening the maturities of borrowings and paying the associated higher debt servicing costs by adjusting the amount, the composition of foreign exchange reserves, and by reviewing criteria and government arrangements in respect of contingent liabilities are used to address debt market crises. From the point of the central bank, additional resident sourced sovereign debt would also reduce the incentive of the government to inflate its debt.

The institutional framework should encompass a legal framework which clarifies the authority to borrow, to issue, invest and undertake transactions by government from borrowed funds while organizational framework should be well specified including roles and mandates. Linking the appropriate Government institutions with the institutions charged with the responsibility of managing public debt is important to ensure proper management of public debt whether domestic or external debt. To ensure accountability and transparency debt management activities should be audited annually by the auditor of government finances or by an external auditor. UNCTAD has assisted countries to come up with a debt management software; the Debt Management Financial and Analysis System (DMFAS) which can be used to manage external and domestic public debt as well as private debt and grants. It can also be integrated into other financial management systems used by government. In managing public debt countries should ensure that the government needs and payment obligations are met at the lowest possible cost over the medium to long-term, and that debt is assumed with a prudent degree of risk. Countries sometimes struggle to access concessional borrowing majorly at low-interest loans with long payback periods and debt restructuring take priority while others focus on debt that can be traded in in the capital market (Rodrigo, 2015).

\section{RESEARCH PROBLEM}

Foreign debt is cheaper for any developing countries in terms of interest costs. The lending countries tend to impose conditionality's making it difficult for these countries to access the cheaper foreign debt. Resources to meet the obligatory repayments of foreign debt are limited. Governments should therefore seek to ensure that both the level and rate of growth in their public debt is sustainable and can be serviced under a wide range of circumstances while meeting cost and risk objectives. Foreign debt managers should ensure that the fiscal authorities are aware of the impact of government financing requirements and foreign debt levels on borrowing costs. For some countries public debt alone is not sufficient because the level of public domestic and public external debt and their cost implications is also necessary for informing policy.

IMF and World Bank (2001) posits that the important ratios to measure debt sustainability are public debt to GDP ratio, public debt to government expenditure, public debt to tax revenues and debt service ratio. The debt structure of borrowing by 


\section{The Effect of Foreign Debt and Taxation on Government Expenditure in Kenya}

government which also an important parameter is measured by dividing foreign debt by total public debt to get an indication of the level of foreign debt in terms of domestic versus external public debt which are the main types of public borrowings by government. The debt service ratio which denotes total debt service to total debt is an indicator of the cost of public debt. Many governments seek to support debt structures by establishing where feasible, portfolio benchmarks related to the desired currency composition, duration, and maturity structure of the debt to guide the future composition of the debt portfolio. With respect to external debt management, domestic issuance would also reduce the currency risks faced by national government. Greater domestic issuance in domestic currency is said to reduce financial stability concerns. The shift from international debt to domestic debt means increasing the cost of servicing the debt since domestic debt is more costly than external debt in terms of interest costs. To ensure financial stability, the attractiveness of public debt to foreign investors should not be underscored while realizing that most public debt has historically been held by residents. The need for liquidity calls for issue of short-term treasury bills which have negative implications for capital market development and long-term financial and macroeconomic stability (Martinez Vazquez \& McNab, 2001).

The Kenya Government has reported high foreign debt levels the debt levels of which do not assume a downward trend but instead continue escalating from one year to another. The major concern is whether the Kenya Government should raise more of foreign debt which is cheaper in terms of interest costs while adhering to the conditionality's of lending Countries. Are moneys from foreign debt funding sufficient or is the country forced to still borrow from the more expensive domestic debt? It is thus feasible to establish the effect of foreign debt and taxation on government expenditure of the Kenya government.

\section{CONCEPTUAL FRAMEWORK}

Foreign debt is favored by most countries because it is cheaper to service in terms of interest costs. Foreign debt tends to have an effect on government expenditure. Essentially foreign debt is expected to finance expenditures that are recommended by the lending country abroad. More borrowing abroad is expected to increase government expenditure since most governments borrow to spend anyway. Increased levels of foreign debt increases taxation since governments have to collect high tax revenues to raise enough money to service foreign debt. Therefore, foreign debt is expected to have a positive relationship with taxation. On the contrary high spending levels calls for additional finances some of which is raised by borrowing externally. Increased taxation is required to finance government expenditure. There is an expected positive relationship between taxation and government expenditure. Therefore, even when governments borrow government needs to spend the borrowed money on productive activities and value adding government projects to achieve economic development. There is need to establish the effect of foreign debt and taxation combined on government expenditure.

The conceptual model is as follows

INDEPENDENT VARIABLES

\section{DEPENDENT VARIABLE}

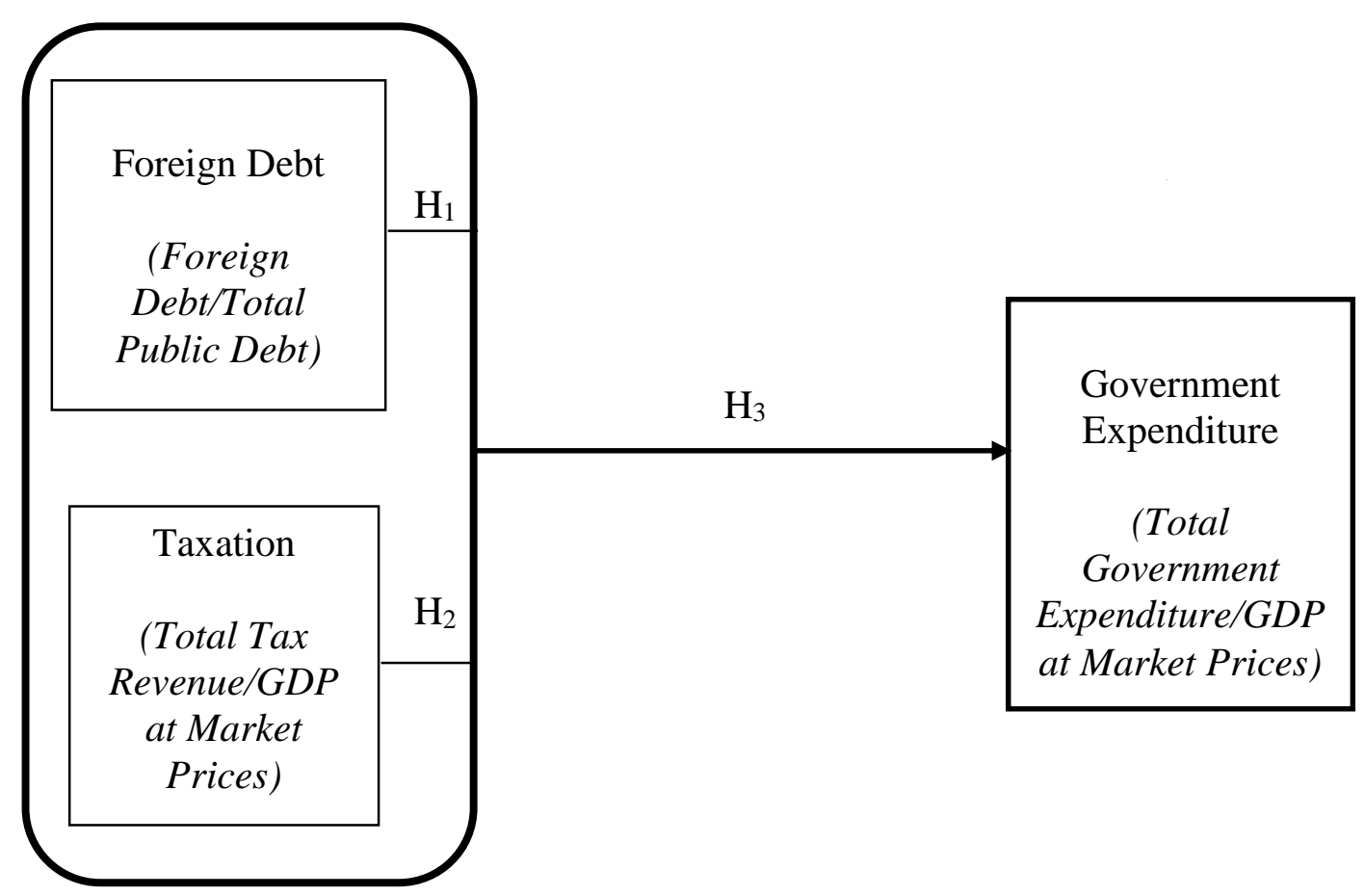

Figure 1: Conceptual Model 


\section{The Effect of Foreign Debt and Taxation on Government Expenditure in Kenya}

\section{METHODOLOGY}

The study employed a causal research design to establish the effect of foreign debt and taxation on government expenditure in Kenya. The period under study ranged from 2002 to 2017 which was considered long enough to enable the researcher to derive conclusions and recommendations based on the study findings. Foreign debt was measured using a ratio of foreign debt/total public debt. Taxation was measured using total tax revenue/GDP. Government expenditure was measured as a ratio of total government expenditure/GDP. The study used secondary data which was extracted from the National Bureau of Statistics, and National Economic Surveys which were available at the Government of Kenya website. Descriptive statistics was used to test the magnitude of the study variables. Regression analysis was used to establish the effect of foreign debt and taxation on government expenditure in Kenya. The regression model was stated as below;

$Y=\alpha+\beta_{1} X_{1}+\beta_{2} X_{2}$

Where $Y$ is government expenditure, $X_{1}$ is foreign debt, $X_{2}$ is taxation, $\alpha$ is the constant term, and $\beta_{1}$ and $\beta_{2}$ are the regression coefficients of predictor variables.

\section{Research Findings}

The research findings were analyzed through inferential analysis where the study employed use of tests of correlation statistics and regression model to estimate the effect of the causal variables on independent variable.

\section{Correlation Statistics}

The study used Pearson correlation method in estimation of the degree of association that existed between the predictor variables and dependent variable. Coefficients of correlated values $(r)$ were given and significance level was tested based on $p-$ values, using a confidence interval of $95 \%$. Where with the $p$-value $\leq 0.05$, the variable was considered significant. The output is as contained in Table 1.

Table 1: Correlation Estimations

\begin{tabular}{|c|c|c|c|c|}
\hline & & $\begin{array}{l}\text { Government } \\
\text { Expenditure }\end{array}$ & Foreign Debt & Taxation \\
\hline & Pearson Correlation & 1 & $.929^{* *}$ & $.944^{* *}$ \\
\hline \multirow[t]{3}{*}{ Government Expenditure } & Sig. (2-tailed) & & .000 & .000 \\
\hline & $\mathrm{N}$ & 20 & 20 & 20 \\
\hline & Pearson Correlation & $.929^{* *}$ & 1 & $.973^{* *}$ \\
\hline \multirow[t]{3}{*}{ Foreign Debt } & Sig. (2-tailed) & .000 & & .000 \\
\hline & $\mathrm{N}$ & 20 & 20 & 20 \\
\hline & Pearson Correlation & $.944^{* *}$ & $.973^{* *}$ & 1 \\
\hline \multirow[t]{2}{*}{ Taxation } & Sig. (2-tailed) & .000 & .000 & \\
\hline & $\mathrm{N}$ & 20 & 20 & 20 \\
\hline
\end{tabular}

**. Correlation is significant at the 0.01 level (2-tailed).

The study found out that accessibility to foreign debt is statistically associated to an increase in government expenditure given an $r$ value of .929 and a significant $p$ - value of 0.000 . In other words, an increase in the amount borrowed from foreigners/foreign countries can increases chances of government spending more. Taxation was also found to have a significant association towards government expenditure as their relationship produced an $r$ value of $0.944, p$ - value $=0.000$ ). This can also be interpreted to mean that an increase in the rate of taxation is statistically associated with $94.4 \%$ increase in the rate of government expenditure.

\section{Regression Analysis}

The regression was carried out to ascertain the relationship between the study variables. Based on the confidence interval of $95 \%$, the study relied on an error margin of $5 \%(0.05)$. Thus, when the $p$-value $\leq 0.05$, the variable would be considered to be significant.

\section{Relationship between Foreign Debt and Government Expenditure}

The results of the regression model testing the relationship between foreign debt and government expenditure are as shown in Table 2. The summary of the regression model produced an $R$ value of .929. The goodness fit of the model $\left(R^{2}\right)$ was 0.862, meaning that the construct of foreign debt alone has ability of explaining $86.2 \%$ change in government expenditure. An implication that there exist other factors which can be included in the model to improve its goodness of fit. 


\section{The Effect of Foreign Debt and Taxation on Government Expenditure in Kenya}

Table 2: Foreign Debt and Government Expenditure

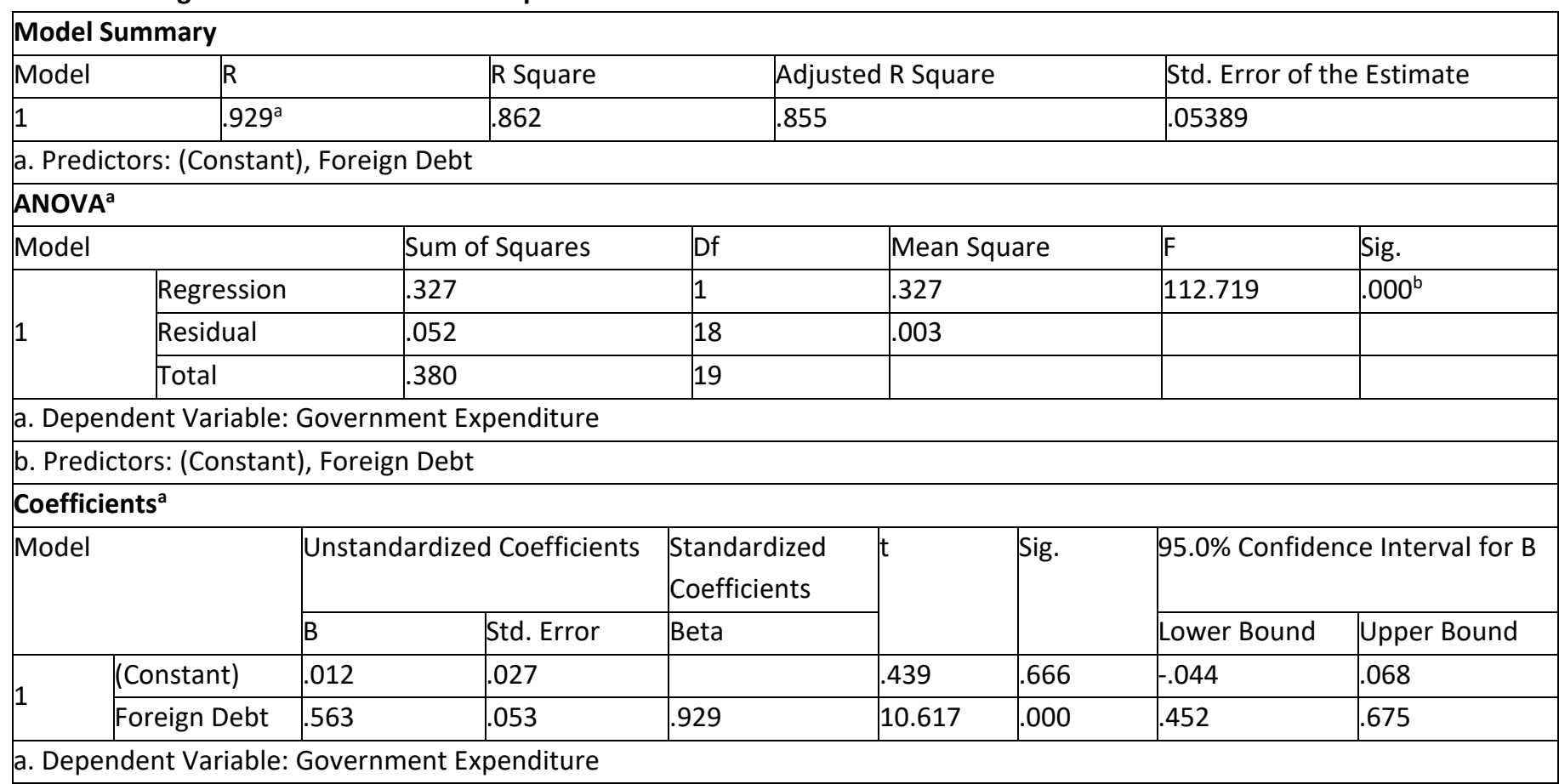

The study tested the null hypothesis that "Foreign debt does not influence Government expenditure". This was done using test of ANOVA where the model gave a regression model provided an $F$ value of 112.719 supported by a strong $p-$ value of 0.000 . This could therefore mean that the study should reject the null hypothesis that foreign debt does not influence government expenditure since the error we make by doing so is zero. The coefficient estimates revealed that foreign debt strongly influence government expenditure given a coefficient value of 0.563 ( $t$-value of 10.617) and $p$-value of 0.000 .

\section{The Effect of Taxation on Government Expenditure}

The study tested the effect of taxation on government expenditure and the results are displayed in Table 3. The model summary indicated a correlation $R$-value of 0.944 and an $R$ squared value of 0.891 . This has indication that taxation was found to have the ability of explaining approximately 89.1 percent of variation in public expenditure.

Table 3: Taxation and Government Expenditure

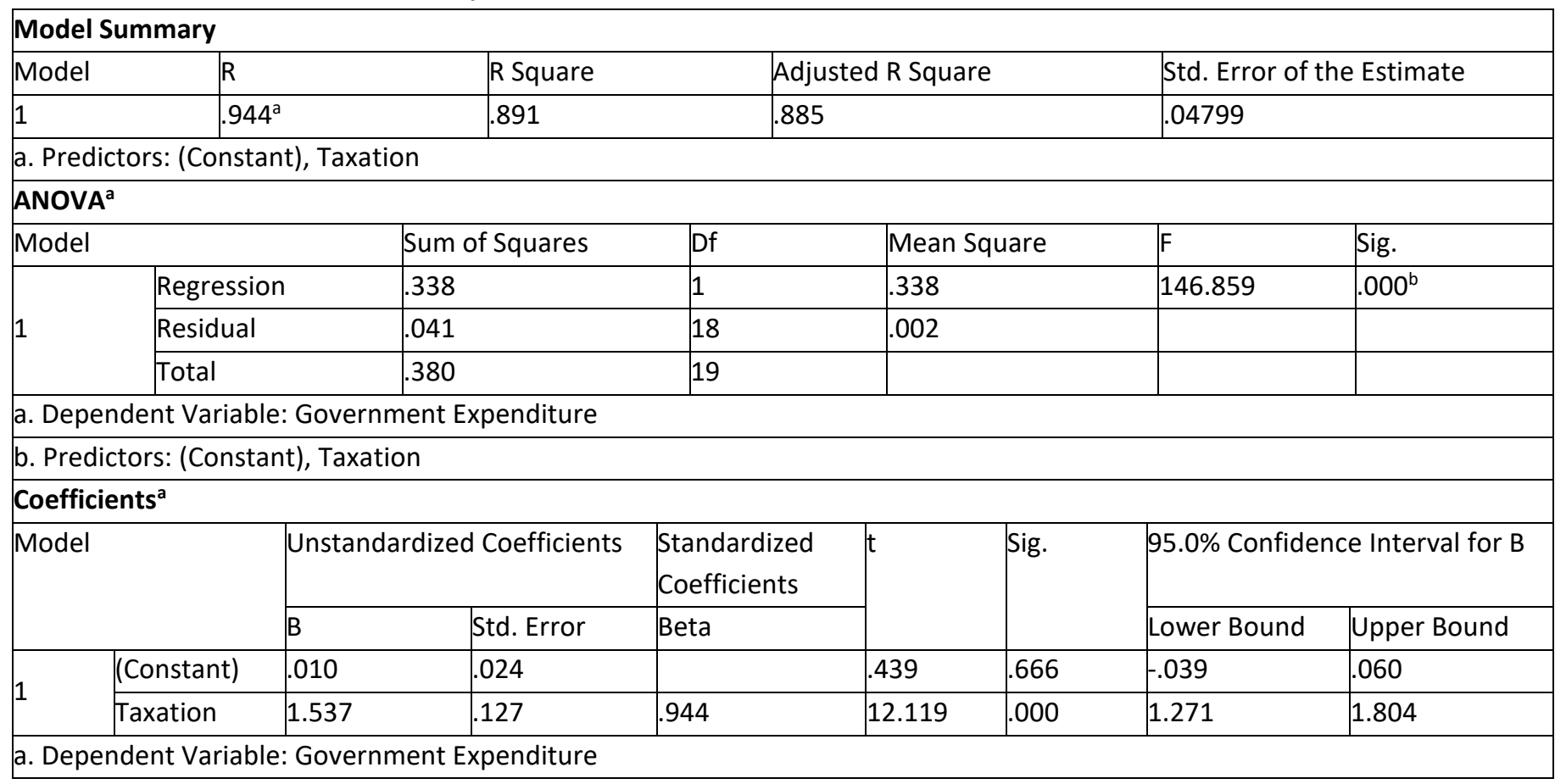

The output of ANOVA gave an $F-$ value of 146.859 and $p-$ value of 0.000 . This revelation therefore informs the study to reject 


\section{The Effect of Foreign Debt and Taxation on Government Expenditure in Kenya}

the null hypothesis that "Taxation does not have significant influence on government expenditure" since the $p-$ value is $<0.05$. Based on coefficient results, it can be construed that taxation has a strong relationship towards expenditure of the Kenyan government. This relationship provided a coefficient value of $1.537(t=12.119)$ and a strong $p$ value of 0.000$)$.

\section{The Joint Effect of Foreign Debt and Taxation on Government Expenditure}

After estimating the effect of individual predictor variable on independent variable, the study resolved to test the combine effect of the two predictor variables under study on public expenditure as shown in Table 4 . The summary results indicate that the regression model provided a combined correlation $R$ - value of 0.945 and an $R$ squared value of 0.893 . This has indication that the foreign debt together with taxation were found to explain approximately 89.3 percent of variation in government expenditure. An indication that there exist other predictor variables not in the model which could be included to improve the model's goodness of fit.

Table 4: Effect of Foreign Debt and Taxation on Government Expenditure

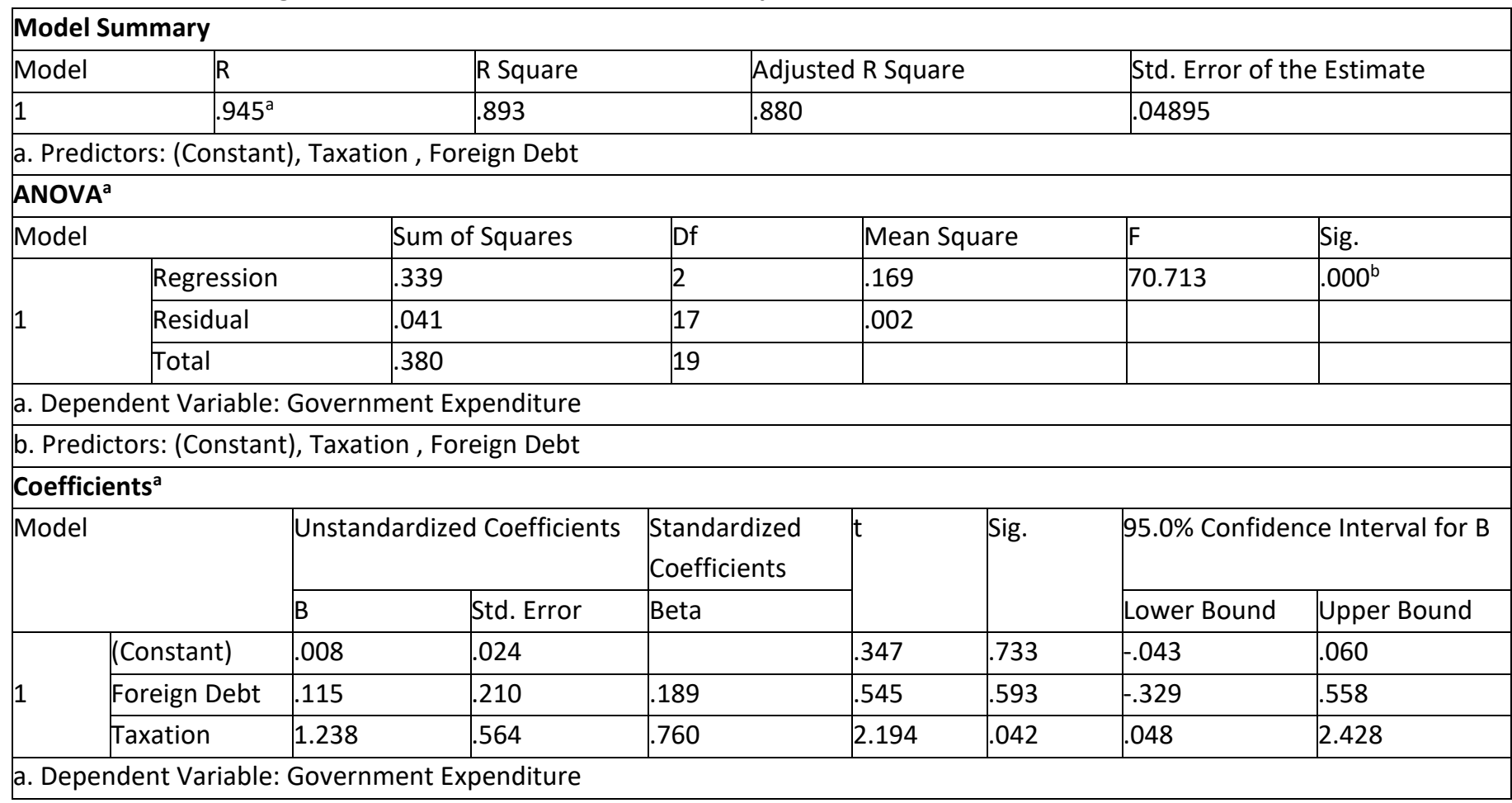

The output of ANOVA gave an $F$ - value of 70.713 and a significant value of 0.000 , the model informs us that the independent variables used in this study were acceptable and fit to determine the dependent variable and therefore an indication that the joint effect of the taxation and foreign debt is significant in influencing expenditure of Kenyan government for a period ranging from 2002 to 2017 . Thus, the study rejects the null hypothesis that foreign debt and taxation do not significantly influence government expenditure. From the joint effect foreign debt does not have a significant effect on government expenditure ( $p$-value=0.593) while taxation has a significant effect on government expenditure $(p$-value $=0.042)$. Therefore jointly it is taxation that significantly influences government expenditure in Kenya.

\section{CONCLUSION AND RECOMMENDATION}

The study concludes that foreign debt and taxation influences government expenditure in their individual tests. This revelation shows that the Kenyan government should not budget basing much on debts but on taxes collected. The results have shown that in absence of taxation, government expenditure can rely on foreign debts. Likewise, without foreign debts, governments can spend based on the available taxes. However, when the two predictor variables are joined together, it was found out that only taxation would have a significant relationship towards public spending. Overdependence on debts can bring about disruptive effects on the domestic economy, especially when the interest charged are high.

Both the foreign debt and taxation tends to increase government expenditure because money that is borrowed from external sources and money which is raised through taxation is spent on financing government activities. The major concern is whether some developing countries such as the Kenya government should raise more of foreign debt which is cheaper in terms of interest costs while adhering to the conditionality of lending countries. Countries make choices between raising foreign debt since lenders 


\section{The Effect of Foreign Debt and Taxation on Government Expenditure in Kenya}

abroad are sometimes hesitant to lend as the impose conditionalities which dictate how much these developing countries can borrow abroad. The almost inevitable result is when a country experiences an increase in foreign borrowings in times of reduction in taxation. The ability to pay back the debts would be far-reaching without stead income generated through taxation. This study therefore recommends that the government should plan to spend based on its available means of raising revenues.

\section{REFERENCES}

1) Abdul Aziz, M. Muzafar Shah, H. (2002). Testing for Causality between Taxation and Government Spending: An Application of Toda-Yamamoto Approach. University Putra Malaysia Press, vol 8; pp 45-50.

2) Alesina A, DeBroekim, Prati A., \& Tabellini G. (1992). Default Risk on Government Debt in OECD Countries, in Economic Policy. European Forum, October. $428-463$

3) Anderson, E. Wallace, $\mathrm{M}$ and Warner J. (1986); Government spending and Taxation: What Causes What? Southern Economic Journal, 52 (3), $630-639$.

4) Auronen L.(2003); "Asymmetric Information: Theory and Applications", Helsinki University of Technology, Department of Industrial Engineering and Management, Lauri.Auronen@hut.fi

5) Bank for International Settlement, Basel (1999). How Should We Design Deep and Liquid Markets? The Case of Government Securities. Committee on the Global Financial System.

6) Barclays M and Holderness C. (1998). Private Benefits from Control of Public Corporations, Journal of Financial Economics, 3.

7) Beaver W. H., (1996), "Financial Ratios as a Predictor of Failure", Empirical Research in Accounting; Selected Studies, 71 $-111$.

8) Brewer M B and Barry E C (1981); Scientific Inquiry and the Social Sciences, San Francisco; Jossey-Bass Publishers

9) Brinberg D \& Joseph M (1985). Validity and the Research Process, Newbury Park, Calif. Sage Publications.

10) Campell D T and Thomas D C (1979); Quasi-Experimentation. Shokie, Rand McNally.

11) Campell I. (2007); Chi-Squared and Fisher_Irwin Tests of Two-By-Two Tables with Small Sample Recommendations, Statist. Med (see also www.iancampell.co.uk/twobytwo/background.htm).

12) Chava F N and David N (1996), Research Methods in the Social Sciences, St Martin's Press, Fifth Edition

13) Chiang A. C (1980), Fundamental Methods of Mathematical Economics, Third Edition; McGraw-Hill International Book Company

14) Chipeta C. (1998). Tax Reform and Tax Yield in Malawi; AERC Research Paper, No. 81

15) Cornia G.A and Stewart F. (1991); The Fiscal System, Adjustment and the Poor; Richerche Economiche, XLIV (2): 349-379.

16) Davide D. (2016). Strategy and tactics in public debt management. Journal of Policy Modelling 38(1), $1-25$

17) Davis J A (1985); The Logic of Causal Order, Newbury Park, Calif, Sage Publications

18) Devarajan s., Rajkumar A.S. and Swaroop V. (1998); What Does Aid to African Finance? AERC/ODC Project on Managing a Smooth Transition from Aid Dependence in Africa, Washington D.C.

19) Gallagher C.A and Watson H. J (1984) Quantitative Methods for Business Decisions, McGraw-Hill International Book Company.

20) Gallagher M (1994); Government Spending in Africa: A Retrospective of the 1980s; Journal of African Economies; 3(1), 62 -92, April.

21) Garba A. G (1997); Is Nigeria's Federal Expenditure Endogenous? African Journal of Economic Policy; 4 (1); 105 - 125

22) Ghura, D (1998); Tax Revenue in Sub-Saharan Africa: Effects of Economic Policies and Corruption, IMF Working Paper.

23) GOK (2011/2012). National Treasury; Debt Management Report 2011/2012, Debt Management Department, National Treasury, Republic of South Africa

24) GOK (2013). The 2013/14 - 2015/16 Medium Term Expenditure Framework (MTEF) Budget - Sector Stakeholders Public Hearings" Held on $12^{\text {th }}$ to $14^{\text {th }}$ November 2012 at the Kenyatta International Conference Centre (KICC).

25) Guinigundo D. C. (2015) Fiscal Policy, Public Debt Management and Government Bond Markets: The Case of the Philliphines $269-283$.

26) Hammersley M (1995); Theory and Evidence in Qualitative Research: Quality and Quantity, Journal of Quantitate Research, 29 (1), 55-66

27) Harding D. \& Pagan, A. (2002). Dissecting the Cycle: A Methodological Investigation. Journal of Monetary Economics, 49: $3812-385$.

28) Hoddinott J, Bates R. H and Steedman C (1994). Government Spending in Africa: A Retrospective of the 1980s; Journal of African Economies, 3(1), April. 


\section{The Effect of Foreign Debt and Taxation on Government Expenditure in Kenya}

29) IMF \& World Bank (2001). Guidelines for Public Debt Management; The international Monetary Fund and the World Bank, March.

30) IMF (2000). Debt and Reserve Related Indicators of External Vulnerability (SM/00/65).

31) Julie C and Strauss A (1996); Basics of Qualitative Research, Techniques and Procedures for Developing Grounded Theory, Sage publications, International Educational and Professional Publisher, Second Edition.

32) Julie C and Strauss A (1996); Basics of Qualitative Research, Techniques and Procedures for Developing Grounded Theory, Sage publications, International Educational and Professional Publisher, Second Edition

33) Khan A.H. (1988); Public Spending and Deficits: Evidence from a Developing Economy; Public Finance, $43(3), 396$ - 402

34) Kirk J. and Miller M (1986); Reliability, Validity and Qualitative Research; Beverly Hills, C.A. Sage Publications.

35) Kusi N. K (1998); Tax Reform and Revenue Productivity in Ghana, Research Paperp74, African Economic Research Consortium, Nairobi.

36) Manage N. and Marlow M (1986); The Causal Relationship Between Federal Expenditures and Receipts; Southern Economic Journal, Vol. 52, No. 3 pp 617-629

37) Marlow, M. and Manage N. (1987); Expenditures and Receipts: Testing for Causality in State and Local Government Finances; Public Choice, Vol. 53, No.3, pp 242-255.

38) Maynand, T. and Guy, K. (2009). The Causal Relationship Between Government Expenditure and Tax Revenue in Barbados; Research Department, Central Bank of Barbados.

39) Melecky, M. (2012). Formulation of Public Debt Management Strategies. An Empirical Study of Possible Drivers; Economic Systems. 36(2), $218-234$

40) Niskanen W. (1978); Deficits, Government Spending, and Inflation: What is the Evidence? Journal of Monetary Economics, August, pp 591-602

41) Ogbu O and Gallagher M (1991); Public Expenditures and Health Care in Africa; Social Science and Medicine, 34(6); 615318.

42) Osoro N. E (1992); Revenue Productivity Implications of Tax Reform in Tanzania, Research Paper 20, African Economic Research Consortium, Nairobi

43) Osoro N. E (1995); Tax Reforms in Tanzania - Motivations, Directions and Implications, Research Paper 38, African Economic Research Consortium, Nairobi.

44) Osoro N.E. (1997); Public Spending, Taxation and Deficits, Research Paper No. 62, African Economic Research Consortium, Nairobi.

45) Provopolous G. and Zambaras A (1991); Testing for Causality Between Government Spending and Taxation; Public Choice, 68: $277-282$.

46) Provopolous, G. (1982), Public Spending and Deficits: The Greek Experience; Public Finance, 37(2), 395-415.

47) Redoblado, J. (2011). Policy Responses to the Global Financial Crisis. The Philliphines Case in Relative Effectiveness of Policy Choices during the Global Crisis in SEACEN economies, in Dheerasinghe R. (2011) (ed.) 391 - 395, Kuala Lumpur. The South East Asian Central Banks (SEACEN).

48) Rodrigo, C. (2015). How strategically is Public Debt is managed around the Globe? Survey of Public Debt Management Strategies. World Bank, March.

49) Sundarajan, V., Dattels, V. and Hans, J. (1997). Coordinating Public Debt and Monetary Management, Washington D.C.; International Monetary Fund.

50) Tanzi V. (1991); Fiscal Propositions in Adjustment Programms; Richerche Economiche, XLIV, 2(3): 173-94

51) Von Furstenberg G.M, Green R.T and Jeong J.H. (1986). Tax and Spend or Spend and Tax; Review of Economics and statistics, 58(2), $179-188$.

52) Wahid, A. (2008). An Empirical Investigation on the Nexus Between Tax Revenue and Government Spending: The Case of Turkey, International Research Journal of Finance and Economics, vol. 16, pp 46-51 